\title{
THE IMPORTANCE OF THE EFFICIENCY OF MUTUAL LIFE INSURERS: A COMPARISON TO STOCK LIFE INSURERS
}

\author{
William Wise, M.ActSt., M.A. (Mathematics) \\ Independent researcher \\ e-mail: bill1612018@mail.com \\ ORCID: 0000-0001-8947-2351
}

Received 4 February 2020, Accepted 19 March 2020

\begin{abstract}
Research background: Mutual companies are a major component of the life insurance industry worldwide and moreover are growing in importance. Efficiency, potentially affected by whether a life insurer company is mutual or stock, can determine how well said companies perform.

Purpose: The aim of this paper is to demonstrate the importance of examining the efficiency of mutual and takaful (similar to mutuals) life insurance companies.

Research methodology: This research coordinates 1) ideas regarding the size and importance of the mutual and takaful life industries worldwide, 2) theoretical aspects concerning how the efficiency of mutual/takafuls is expected to compare to that of stock insurers and 3) the outcomes of germane life insurance efficiency studies.

Results: The outcomes of life insurance efficiency studies tend to show that, in total, stock insurers are more efficient than mutuals apart from one conspicuous element. As mutuals are substantial within several of the world's largest life markets and the global life industry their being inefficient can be exceedingly negative. The overall conclusion is that such inefficiency can lead to dire economic problems so it is imperative to investigate the efficiency of mutuals/takafuls and perhaps the one element of stocks.

Novelty: This article is the first to investigate the results of mutual/takaful life insurer efficiency studies in concert with the abovementioned theory and draws a vital conclusion regarding mutual/takaful life insurer inefficiency.
\end{abstract}

Keywords: life insurance, efficiency, mutual, takaful

JEL classification: G22, G30, L22 


\section{Introduction}

The role of the financial sector in the economic development of any country is critical (Aoba, 2006; Janjua, Akmal, 2015) and so an effective, developed and productive insurance sector ultimately contributes to a nation's economic growth. Mutual companies are a major component of the life insurance industry worldwide and moreover are growing in importance. Therefore the aim of this paper is to demonstrate the importance of examining the efficiency of mutual and takaful (similar to mutuals) life insurance companies.

This research contributes to the literature examining life insurance efficiency in that it puts together and coordinates ideas regarding 1) the size and importance of both the mutual and takaful life industries worldwide; 2) theoretical considerations as to how the efficiency of mutual and takaful ventures might be expected to compare with that of stock and conventional institutions and 3) the outcomes of life insurance efficiency studies on the subject. This leads to a discussion of the importance and consequences of mutual life insurance (in) efficiency as well as a conspicuous element of stock LIC inefficiency.

It is paramount to evaluate accurately how well life insurance companies (LICs) perform and how viable they are for the benefit of other industries and indeed national economies. A case in point is that the bankruptcy of an insurance company may have a disproportionately high negative effect for society as a whole against bankruptcies in other industries (Holzmuller, 2009). Furthermore within the financial services industry, compared to other institutions, the average insurer insolvency involves three to five times greater expense (Grace, Klein, Phillips, 2003).

As commented previously mutual companies are a major component of the life insurance industry worldwide and moreover are growing in importance. According to the International Cooperative and Mutual Insurance Federation (ICMIF) within the global life insurance industry the mutual and cooperative insurance market grew the most rapidly in the ten years after the global financial crisis (i.e. from 2007 to 2017). ${ }^{1}$ During this period global mutual and cooperative life premiums grew by $23.4 \%$ as opposed to only $6.6 \%$ for the total life industry (ICMIF, 2019). This has led to the market share of mutual/cooperative businesses increasing to $22.5 \%$ in 2017 from 19.5\% in 2007 (ICMIF, 2019). In the world's two largest life insurance regions, North America $^{2}$ and Europe, from 2007-2017 mutual life premiums grew by 50.4\% and 14.1\% while the total life premium dropped by $4.2 \%$ and $22.8 \%$. Therefore the life insurance market share

\footnotetext{
1 It should be noted that in this paper health insurance is not included as life insurance as much as possible, in line with the ICMIF analyses to which are referred.

2 As defined by ICMIF - i.e. just the United States and Canada.
} 
of mutuals increased from 22.7 to $35.7 \%$ in North America $^{3}$ and from 17.2 to $25.4 \%$ in Europe (ICMIF, 2019). Another element demonstrating how substantial are mutuals is that overall ${ }^{4}$ mutual/cooperative insurance companies had 922 million members/policyholders in 2017 as well as employing 1.16 million people (ICMIF, 2019).

Rapidly becoming crucial, especially in the realm of mutual life insurance, are the takaful LICs which ICMIF includes in its definition of mutual entities (ICMIF, 2017a; ICMIF, 2019). ${ }^{5}$ As an illustration of this growing prominence, in 2016 the overall worldwide takaful industry had an increase of $12.5 \%$ in contributions in 2016 against only $2.8 \%$ for life insurance globally (Islamic Financial Services Board (IFSB), 2018; Swiss Reinsurance Company Limited (SRC), 2017). Additionally in 2015 (2014) the overall takaful increase in contributions was $13.1 \%(15.5 \%)$ versus $-4.6 \%(+4.3 \%)$ in the life insurance industry and, contrasted with the aforementioned for life insurance, the overall worldwide takaful industry contributions more than tripled between 2008 and 2015 (IFSB, 2017; SRC, 2015; SRC, 2016).

One trait that determines how well life insurers perform is their efficiency with firms with better efficiency achieving greater profits (Cummins, Rubio-Misas, Vencappa, 2017). Several papers exhibit directly how the efficiency of a LIC can affect their profits and hence viability with examples being W. Greene and D. Segal (2004), M.Z.A. Karim and C. Jhantasana (2005), B. Liu (2007), A.L. Alhassan and G.K. Addison (2013) and W. Wise (2018). W. Greene and D. Segal (2004) conclude that life company inefficiency decreases the average ROE (ROA) of the industry from 12 to $8 \%$ ( 2 to $1 \%$ ) on an annual basis which are both clearly substantial. On a cumulative basis (which takes into account all available years for each venture) the outcome is that LIC inefficiency decreases the average ROE (ROA) of the industry from 8 to $3 \%$ (1.2 to $-0.3 \%$ ); even more economically crucial than the single year results.

M.Z.A. Karim and C. Jhantasana (2005) finds for both the natural log of ROE and the natural log of ROA inefficiency decreases profit at a 5\% significance level for all three models considered. Likewise A.L. Alhassan and G.K. Addison (2013) deduces that the life insurer ROA

\footnotetext{
${ }^{3}$ Using a more complete definition of North America, the data from Appendices I \& II of ICMIF (2017a) show that in the largest eight countries in North America mutuals had about 31.6\% of the life insurance market share in 2015.

${ }^{4}$ Overall is both life insurance and general insurance.

${ }_{5}$ Takaful, a.k.a. Islamic or sharia insurance, is similar to mutual insurance in that takaful insurers are owned by their policyholders who assume the insurance risk and share in the profits and losses of the takaful enterprise (Al-Amri, Hossain, 2015; Jaffer, Ismail, Noor, Unwin, 2010; PricewaterhouseCoopers, 2008). Takaful is different from conventional insurance as the latter has the attributes contrary to Islamic law of riba (usury), gharar (ambiguity), and maisir (gambling) (Lim, Idris, Carissa, 2010; Shafique, Ahmad, Ahmad, Adil, 2015). Takaful, on the other hand, is based on the philosophies of mutual assistance, responsibility, protection and (voluntary) risk sharing through mutual cooperation (Abdou, Ali, Lister, 2014; Khan, Noreen, 2014). The word takaful, originates from the Arabic word kafala, which means "guaranteeing each other" or "joint benefit" or "shared responsibility" (Al-Amri, Hossain, 2015). Takaful life insurance is also called family takaful.
} 
decreases with inefficiency for life institutions. Assuming VRS the coefficient for one model has a $1 \%$ significance level and in the other two models used the coefficient has a $5 \%$ significance level. With CRS the coefficient has a 5\% significance level for all three models utilized.

B. Liu (2007) probes the regressions of ROA and ROE against efficiency and declares that ROA decreases with efficiency, the relevant coefficient having statistical significance whereas the coefficient for ROE is not significant to a 5\% level. Wise (2018) observes that inefficiency reduces the profit of life businesses with a statistical significance of $1 \%$ in three of four models explored and that the best and possibly the only way for life entities to improve profit is via improving efficiency.

Now, as shown below, efficiency can be greatly affected by the ownership form of a life firm, i.e. mutual versus stock companies. For takaful insurance, similar to mutual insurance, the efficiency of life insurers is also critical, being up against well-established conventional life insurance companies (Khan, Noreen 2014).

Overall, then, 1) the life insurance industry is key to the economy of most countries; 2) mutuals/takafuls are both prominent and growing more so in the life insurance industry as displayed above and in Section 3;3) efficiency is central to the profitability and viability of LICs and 4) at least in theory mutuals/takafuls tend to be somewhat less efficient that stocks/ conventionals (see Section 4). Therefore it is necessary to investigate the efficiency of mutuals/ takafuls.

This paper continues with a review of the relevant literature in Section 1. Section 2 describes the research method used. Section 3 presents an analysis/demonstration of how the mutual life industry is a major piece of the global life industry via a country-by-country scrutiny and Section 4 probes at how the efficiency of mutuals can be expected to compare to that of stock businesses in theory. Section 5 illustrates the results of the articles in detail, co-ordinates these with the theory from Section 3 and offers a discussion. The last section concludes and gives suggestions for further research.

\section{Literature Review}

There have been twenty-six truly different applicable studies (contained in twenty-five papers) found that actually compare the efficiency of stock life insurers to that of mutual life insurers (even if just incidentally) along with four others that concern themselves with characteristics related to the efficiency of stocks versus mutuals. As well there have been eighteen 
truly distinct suitable works observed that in fact contrast the efficiency of stock/conventional life companies with that of takaful/sharia life companies.

The earliest LIC research seen is F. Fecher, D. Kessler, S. Perelman and P. Pestieau (1993) and L.A. Gardner and M.F. Grace (1993). ${ }^{6}$ F. Fecher et al. (1993) explores 84 French life enterprises using data from 1984-1989. Incorporating three DEA models and one SFA model the paper depicts that the efficiency of stock entities equals that of mutuals in all four models ${ }^{7}$ (though this was not the main drive of the item). Gardner and Grace (1993) investigates 561 United States firms with data from 1985-1990. First drawing on DFA to assess the efficiency of the insurers, a second stage of regressing efficiency against variables including organizational form is utilized and it is portrayed that being mutual has no effect on institution efficiency as the relevant coefficient has no statistical significance.

The next studies found are several from 1997. H. Fukuyama (1997) uses 1988-1993 data on twenty-five Japanese life establishments. With DEA the author proclaims that there is no statistical difference in efficiency between the two organizational forms at the $5 \%$ level of significance. P. Hardwick (1997) employs SFA on fifty-four LICs in the UK with data from 1989-1993 and also notes no statistical difference in efficiency between the two organizational forms at the 5\% level of significance. J.W. Meador, H.E. Ryan, Jr. and C.D. Schellhorn (1997) applies DFA to 358 US life insurers using data from 1990-1995. The piece conveys that being mutual has no effect on efficiency as the coefficient in the regression of efficiency against variables including organizational form has no significance. The last paper from 1997 observed is J.D. Cummins and H. Zi (1997) which compares the efficiency outcomes for 445 US life ventures with 1988-1992 data when incorporating five parametric as opposed to four nonparametric methods. After accounting for size, it is asserted that there is no statistical difference in efficiency between the two organizational forms at the $5 \%$ level of significance.

The other twenty-two truly dissimilar readings are from the years 1999 through 2018, consider efficiency from diverse places for instance the United States, Europe and Japan and draw upon the procedures of SFA, DFA and DEA. The details of the results of these studies are displayed in Section 5 (Table 2)

The investigation of the efficiency of takaful life insurance companies started later with the first article seen from 2006. Even so the first item found with a reasonable number of takaful

\footnotetext{
${ }^{6}$ A previous work, Grace and Timme (1992), does not actually calculate efficiency as such but it does utilize a hybrid translog function (which employs the natural log of input prices and a Box-Cox transform of output values) including a mutual dummy variable to evaluate the cost structures of 423 US LICs for the year 1987. The research estimates that stocks have a better cost structure than do mutuals with a $1 \%$ statistical significance.

7 As the difference between the efficiency scores of the two sets show no significance using Welch's t-test.
} 
insurers was not until 2011. ${ }^{8}$ However this writing, N. Ismail, D.S.O. Alhabshi and O.I. Bacha (2011), is virtually identical to N. Ismail, D.S.O. Alhabshi and O.I. Bacha (2013) cited below and only appraises technical efficiency, not cost or profit efficiency. Therefore the earliest applicable paper observed that contrasts takaful LIC efficiency with that of conventional life businesses is M. Abduh, M.A. Omar and R.M. Tarmizi (2012) which inspects both DEA and a ratio analysis for twelve Malaysian companies (five of which are takaful) with data from 2008-2010. The piece does have two basic problems, nonetheless, in that it 1) does not separate life from general insurance (see footnote 17) and 2) has a questionable number of entities versus that of inputs and outputs. ${ }^{9}$ The authors exhibit that the efficiency of non-takaful institutions is better than that of takafuls when looking at both DEA and ratio analysis. The statistical significance of the former result is $10 \%$.

After 2012 there has been a rapid increase in the quantity of readings comparing takaful and non-takaful life insurers. For 2013 four studies have been found. N. Ismail, D.S.O. Alhabshi and O.I. Bacha (2013) scrutinizes the efficiency of eighteen Malaysian life establishments (seven of which are takaful) with DEA. The data from 2004-2009 indicate that, using Welch's t-test, the cost efficiency of non-takafuls is better than that of takafuls with a $1 \%$ statistical significance. Rahman (2013) explores thirteen LICs of Bangladesh incorporating DEA with data from 2009-11 with the outcome that, from Welch's t-test, there is no statistical significance to any difference between the two forms. M.S. Antonio, M.M. Ali and N. Akbar (2013) draws on DEA to examine twenty-six life firms in Malaysia with data from 2009-2011 and elucidates that the two forms have equal overall efficiency on average as the difference calculated between the two has no statistical significance. The last work from 2013 observed is A. Singh and Z. Zahran (2013) which utilizes each of SFA, DEA and FDH on thirty-two life concerns of Bahrain, Egypt, Jordan, Kuwait, Qatar, the KSA, Tunisia and the UAE with data from 2005-2008. The conclusion from SFA is that stock businesses are more efficient at the $10 \%$ significance level. Going yearby-year the decisions when employing DEA are that either stocks have greater efficiency with statistical significance or there is no difference in the efficiencies between the two and for FDH are that there is no difference in the efficiencies between the two.

\footnotetext{
8 Saad, Majid, Yusof, Duasa, Rahman (2006) has only one takaful of thirteen insurers, Saad, Idris (2011) only one of eleven, Yusop, Radam, Ismail, Yakob (2011) only two of seventeen.

${ }^{9}$ If the number of DMUs is low when compared to that of inputs and outputs a high proportion will have an efficiency score of $100 \%$ as they will be difficult to match in all dimensions (Bauer, Berger, Ferrier, Humphrey, 1998; Thanassoulis, Portel, Despic, 2008). Dyson, et al. (2001) points out that if using DEA a study should have a number of DMUs that is at least as large as twice the product of the number of inputs and that of outputs while Cooper, Li, Seiford, Thrall, Zhu (2001) remarks that the number of DMUs should be at least three times the sum of said two numbers.
} 
The other truly disparate articles range as being from the years 2014 through 2019, concern efficiency from places such as Malaysia, Indonesia and the KSA and apply DEA. The details of the results of this research are portrayed in Section 5 (Table 3).

\section{Research Method}

The emphasis of this paper is an exploration of the results of life insurance efficiency studies comparing the efficiency of mutual and takaful LICs to that of stock and conventional insurers. An investigation of the size and importance of both the mutual and takaful life industries worldwide is first executed. Said investigation demonstrates that analyzing the efficiency of mutuals/takafuls is essential and worthwhile. Theoretical considerations as to how the efficiency of mutual and takaful ventures might be expected to compare with that of stock and conventional institutions are also examined to see if they tend to confirm the outcome of the exploration of the aforementioned efficiency studies.

\section{The Importance of Mutuals in the World's Biggest Life Markets}

The importance of mutuals to the global life insurance industry as mentioned prior is emphasized when looking at the largest individual countries in terms of life premium written. Another manner to quantify the relative sizes of life institutions is by investigating their asset size. However it is difficult to measure the assets of insurance companies (ICMIF, 2017a; ICMIF, 2019) and specifically LICs. Accordingly the estimates of the assets of mutual against stocks illustrated below are by necessity more approximate than the other similar estimates.

In the world's largest life market, the United States, ${ }^{10} 109$ of 773 life enterprises were mutual in 2018, greater than 14\% of the total (Statistics Portal, 2020a; Statistics Portal, 2020b). US life insurance mutual premiums grew by 10.1\% from 2007-2017 (ICMIF, 2019). Furthermore in 2015 mutuals wrote $33.4 \%$ of all life premiums in the United States (ICMIF, 2017) ${ }^{11}$ and on average between 2012 and 2015 these ventures held about $44 \%$ of total life insurer assets in the

\footnotetext{
${ }_{10}$ Rankings are all from SRC (2019) taking account the caveats therein. For data Puerto Rico is amalgamated into the US and Hong Kong into the PRC.

11 Note that, from ICMIF (2017a) p. 34 and ICMIF (2019) p. 19, ICMIF's definition of "mutual" and "cooperative" includes organisations with a structure and values reflecting the mutual/cooperative form. So said firms are owned by, governed by and operated in the interests of their member policyholders. Hence they "include limited companies owned by people-based organisations, fraternal benefit societies (fraternals), friendly societies, Takaful providers, reciprocals, non-profits, exchanges, discretionary mutuals, protection and indemnity (P\&I) clubs, community organisations and foundations."
} 
United States (author's calculation using data from ICMIF, 2016a; ICMIF, 2017a; Organization for Economic Co-operation and Development (OECD) Datasets).

Moreover in 2015 firms paying policyholder dividends wrote $64.9 \%$ of the sum of direct life premiums and annuity considerations and these companies held $73.9 \%$ of all of the assets held by LICs in the United States (National Association of Insurance Commissioners, 2016). Even though not all of this last set are mutual, there are features within them associated with the efficiency of mutuals for instance higher administration costs related to paying policyholder dividends, checking or changing the dividend scale and elements with respect to valuation (see Section 4).

In the world's second largest life insurance market, Japan, in 2015 five of forty-one life entities were mutual (Life Insurance Association of Japan (LIAJ), 2015), more than 12\% of the total. The mutuals wrote $42.4 \%$ of the total life premiums (ICMIF, 2017a). Additionally in 2016 these businesses held about $45.6 \%$ of total life company assets in Japan (Banks Around the World, 2018; LIAJ, 2017).

For Europe's biggest life market, the United Kingdom, 56.0\% of ventures issuing life insurance were mutual at year-end 2015 (Association of Mutual Insurers and Insurance Cooperatives in Europe (AMICE) \& ICMIF, 2018). Nevertheless mutual premiums were only $6.6 \%$ of the life insurer total in 2016 (ICMIF, 2016c) and on average between 2012 and 2015 these institutions only held about 7\% of total LIC assets in the UK (author's calculation using data from ICMIF, 2016a; ICMIF, 2017a; OECD Datasets).

For France around 35\% of the concerns issuing life premiums are mutual (Bank of England, 2018). The mutuals wrote $42.5 \%$ of the total life premiums in 2016 (ICMIF, 2016b). As well on average between 2013 and 2018 these enterprises held about $36.6 \%$ of total life insurer assets in France (author's calculation using data from AMICE \& ICMIF, 2018; ICMIF, 2016a; ICMIF, 2016b; ICMIF, 2017a; Insurance Edge Editor, 2019; OECD Datasets; Terzo, 2019). Table 1 depicts some pertinent statistics regarding mutuals in the world's largest life markets.

Table 1 shows that mutuals (still) make up a substantial portion of several of the largest life insurance markets in the world. This is in addition to the importance of mutuals on a worldwide basis demonstrated in the Introduction.

Similar to mutuals, takafuls are prominent in many of the countries in which they exist and are further becoming more essential to the global life insurance industry. One source declares that the overall worldwide takaful market will be bigger than forty billion USD by 2023 which represents a growth rate of 13\% per year from 2017-2023 (CISION PR Newswire, 2018). Consider some of the largest individual countries in terms of total life premiums where takafuls have some prominence (the rankings in parenthesis are from SRC, 2019). 
Table 1. Pertinent Statistics Regarding Mutual Life Insurance Companies in the World's Largest Life Insurance Markets

\begin{tabular}{|l|c|c|c|}
\hline \multicolumn{1}{|c|}{$\begin{array}{c}\text { Country } \\
\text { (Rank) }\end{array}$} & $\begin{array}{c}\text { Percent of LICs that are } \\
\text { Mutual (year) }\end{array}$ & $\begin{array}{c}\text { Percent of life premiums written } \\
\text { by Mutuals (year) }\end{array}$ & $\begin{array}{c}\text { Percent of LIC Assets held } \\
\text { by Mutuals (years) }\end{array}$ \\
\hline USA (1) & $14.1 \%(2018)$ & $33.4 \%(2015)^{\mathrm{a}}$ & about 44\% $(2012-2015)^{\mathrm{b}}$ \\
\hline Japan (2) & $12.2 \%(2015)$ & $42.4 \%(2015)$ & Miniscule \\
\hline PRC (3) & Miniscule & Miniscule & about $7 \%(2012-2015)$ \\
\hline UK (4) & $56.0 \%(2015)$ & $6.6 \%(2016)$ & about 36.6\% $(2013-2018)$ \\
\hline France (5) & about $35 \%$ & $42.5 \%(2016)$ & about $16.6 \%(2012-2015)^{\mathrm{f}}$ \\
\hline Italy (6) & $35.7 \%(2015)^{\mathrm{d}}$ & $14.4 \%(2016)^{\mathrm{e}}$ & None \\
\hline ROChina (7) & None $(2017)^{\mathrm{g}}$ & None & $7.5 \%(2018)^{\mathrm{h}}$ \\
\hline ROK (8) & $4.2 \%(2018)^{\mathrm{h}}$ & $6.8 \%(2018)^{\mathrm{h}}$ & about $43 \%(2012-2015)^{\mathrm{f}}$ \\
\hline Germany (9) & $50.0 \%(2015)^{\mathrm{d}}$ & $40.8 \%(2016)^{\mathrm{e}}$ & \\
\hline
\end{tabular}

${ }^{a}$ Also LICs paying policyholder dividends wrote $64.9 \%$ of direct life premiums and annuity considerations.

${ }^{\mathrm{b}}$ Also life insurers paying policyholder dividends held $73.9 \%$ of all LIC assets.

c Only in June 2016 did the China Insurance Regulatory Commission approve the establishment of three mutual insurance associations for the first time (ICMIF, 2017b).

${ }^{\mathrm{d}}$ ICMIF (2016b).

e AMICE \& ICMIF (2018). Germany includes LICs writing funeral insurance.

${ }^{\mathrm{f}}$ Author's calculation using data from ICMIF (2016a), ICMIF (2017a), OECD Datasets.

${ }^{g}$ No mutual business recorded in 2017 (ICMIF, 2019).

${ }^{\text {h }} 1$ of 24 life insurers. Source is Korea Life Insurance Association (2019).

Source: author's own compilation.

In Indonesia $\left(27^{\text {th }}\right)$ in 2017 about $6.5 \%$ of all life company premiums were through takaful/ sharia entities (Dhiti, 2018) growing from about 2.8\% in 2014 (KPMG, 2016; SRC, 2015). This increase has prompted a prediction that sharia life insurance will be the fastest growing segment of the life market in Indonesia (KPMG, 2016). In Malaysia $\left(30^{\text {th }}\right)$ almost $17 \%$ of life premiums written were takaful in 2014 and 2015 (Bank Negara Malaysia, 2016). Moreover new business life takaful premiums were $30.5 \%$ of all new business life premiums in the first half of 2017 which illustrates in Malaysia that takafuls are becoming more crucial (Singh, 2018).

In the UAE $\left(40^{\text {th }}\right)$ in 2015 around $11.5 \%$ of all life enterprise premiums were takaful (Milliman, 2017). Morocco $\left(44^{\text {th }}\right)$ started to allow the issuing of takaful life in 2019 (Maierbrugger, 2019) meaning it will clearly become a greater facet of life insurance there while in Pakistan $\left(45^{\text {th }}\right)$ family takaful was $11.1 \%$ of all life firm premiums in 2018 , which was more than a doubling of market share since 2015 (Hanif, Munir, 2019). It was only in 2014 that conventional life insurers have been allowed to issue takaful business thus undoubtedly takaful life will increase continue to increase its market share quickly (Alam, 2015). In Egypt (58 $\left.{ }^{\text {th }}\right)$ in 
the first four months of 2016 takaful premiums were about $12 \%$ of all life premiums (Oxford Business Group).

In Iran $\left(53^{\text {rd }}\right)$ regulations dictate that all life insurance be issued as takaful (Simmons, Siddiqui, 2011). Likewise in the KSA $\left(71^{\text {st }}\right) 100 \%$ of life premiums were written by takaful institutions in 2015 and 2016 (IFSB, 2017; IFSB, 2018) due to regulations (IFSB, 2017; Milliman, 2017).

Therefore it appears that takafuls are either already a substantial percentage of the life market in these countries or have the real potential to become so. The latter is because the density $^{12}$ of life insurance of countries with low percentages of life premiums being takaful is small but increasing. Consequently as takaful is gaining in popularity it will probably take up a relatively large percentage of this overall increase in life premiums.

As the preceding demonstrates, a major number of LICs are (still) mutual; the percentage of life premiums written by mutuals is at least fairly big and seems to increasing. As well on a country-by-country basis it can be seen that for many of the world's largest life markets mutuals (still) hold a sizeable piece of the assets held by life companies. Furthermore takaful LICs are already prominent or look to become so. Hence it can be concluded as key to determine if mutual LICs have greater or less efficiency than stock LICs.

\section{Mutual versus Stock Efficiency - A Comparison in Theory}

Prima facie there seem to be more reasons that mutuals would be less efficient than stock insurers than vice-versa. The most important might be that mutuals have greater difficulty in increasing capital as they have limited methods to do so (O'Hara, 1981; Viswanathan, Cummins, 2003). Profit generated from premiums is one means (Hansmann, 1985) however is limited due to the expectation of returning some profit/premium to the policyholders. The other main way is by issuing debt as opposed to selling shares. The problem is that type of action leads to a higher debt to equity ratio with the outcome of less favorable balance sheets. Accordingly mutuals are forced to issue debt at a higher interest rate than are stock ventures (Erhemjamts, Leverty, 2010). Moreover the transparency of the financial statements of stock establishments tends to be greater which often results in better terms when borrowing (Viswanathan, Cummins, 2003). Mutuals being less efficient may additionally occur because they have to keep a larger amount of capital on hand to guard against not having enough for regulatory purposes if there

12 Density is amount per capita of premiums spent on insurance. SRC studies show that from 2014-2018 the density of life insurance in Indonesia, Malaysia, UAE, Morocco, Pakistan and Egypt increased by 74.1, 30.9, 27.2, 93.7, 72.0 and $61.3 \%$, respectively. 
is a sudden drop in asset values or unanticipated investment losses (Viswanathan, Cummins, 2003). The latter idea also leads to mutual life firms not being able to expand as quickly as can stocks to accommodate an increase in demand (Hansmann, 1985) which can result in missed opportunities to increase company efficiency. Stock concerns, on the other hand, can more easily achieve greater efficiency than can mutuals in this area having the capability to generate capital using the same methods as mutuals but they can also issue more shares (O'Hara, 1981; Viswanathan, Cummins, 2003).

Another reason that mutuals are less efficient is that they have higher administration costs (O'Hara, 1981) due to having to both calculate dividends and pay them. Further cost can come from the fact that mutual life insurers have to check and/or change their dividend scale with much larger frequency than do stocks as all of their policies are par (as distinguished from less than all - or none - being so for the latter). ${ }^{13}$ The higher costs along with the higher interest rate paid for debt can combine to create higher reserve requirements because of a lower valuation interest due to conservatism concerns. The higher debt to equity ratio, interest rate and administration costs have the outcome of higher capital requirements for mutuals than for stocks as well. Such requirements lead to mutuals being less efficient due to less flexibility as to how and where the enterprise can invest and thus less potential investment returns.

One more important reason that mutuals will attain less efficiency is the (possible) cost associated with controlling management. Convincing management to maximize the owner's wealth is a challenge that exists at every level of management and organization in companies (Jensen, Meckling, 1976). The cost of aligning the interests of managers with that of the owners is referred to as agency costs (Cole, McNamara, Wells, 1995) which differ between mutuals and stocks with that of the former being higher (Mayers, Smith, 1981; Mayers, Smith, 1988).

The higher cost of controlling management is due to policyholders, not shareholders, owning the business (Jeng, Lai, McNamara, 2007; Kim, Grace, 1995; Lamm-Tennant, Starks, 1993). These potentially higher operating expenses (Ubl, 2010) may be because, as agency theory predicts, agents that are monitored less strictly will incur greater cost (Boose, 1990). ${ }^{14}$ One fundamental manner shareholders can utilize to decrease unwanted expenses forced onto them by management is (threatening) a takeover. When enough shares are amassed to control the institution, management can then be changed (Mayers, Smith, 1981; Mayers, Smith, 1994).

\footnotetext{
13 Changing, or even just checking, a dividend scale can be considered to be the biggest, most expensive activity a LIC can undertake as all (par) policies need to be evaluated almost on a seriatim basis.

14 This is known as the "expense preference hypothesis" of organizational form which predicts that the costs for mutuals will be higher than for stocks as the stock market is more effective at corporate control and therefore can decrease excessive managerial perquisites.
} 
Controlling the management of stock firms is additionally easier because it is monitored in capital markets ${ }^{15}$ by analysts, institutional investors, and other large stockholders (Cole et al., 1995; Erhemjamts, Leverty, 2010; Wells, Cox, Gaver, 1995). Capital markets signal the value of a firm which can be a principal component when assessing management performance (Fama, 1980). Management in stock companies can moreover be scrutinized via stock options, which cannot be done in mutuals (Viswanathan, Cummins, 2003; Cole et al., 1995).

In mutuals the policyholders need a proxy to change management however 1) proxy fights can be expensive which decreases the motivation to correct the situation (Cole et al., 1995; Mayers, Smith, 1981; Mayers, Smith, 1994) and 2) the benefit to individual policyholders is smaller contrary to what individuals with big shareholdings would gain from a management change (Mayers, Smith, 1988; Mayers, Smith, 1994; Wells et al., 1995). Furthermore the large number and/or scattering of policyholders (Cole et al., 1995; Hansmann, 1985; Lamm-Tennant, Starks, 1993) outcomes in their acquiring little governance of management in mutuals (Cole et al., 1995; Hansmann, 1985; O'Hara, 1981). Also in the few mutuals where policyholders are allowed to vote for members of the board, policyholder voting tends to be exceedingly low (Schiff, 1998; Viswanathan, Cummins, 2003). Another aspect of mutuals is that the assets are controlled by the managers (Fama, Jensen, 1983) meaning there is greater difficulty in controlling them. The consequent overall lack of ability to control management results in less efficiency for mutuals due to the higher perquisite consumption of management because watching management closely enough to prevent it is too costly (Carson, Forster, McNamara, 1998; Cole et al., 1995; O’Hara, 1981).

Free cash flow is additionally a substantial element with an outcome of less efficiency in mutuals contrasted with stocks. M.C. Jensen (1986) introduced and defined free cash flow as cash in excess of that necessary to fund all positive net present value projects. B.P. Wells et al. (1995) found that in the US life insurance industry the managers of mutuals retain considerably more cash flow than their stock establishment counterparts. Free cash flow tempts managers to enhance their control and personal remuneration by investing in projects with non-positive net present values (Jensen, 1986; Mann, Sicherman, 1991; Wells et al., 1995). This can lead to economic inefficiency (Cole et al., 1995) because if managers distributed free cash flow the shareholders could then find ways to exploit it with greater efficiency (Mann, Sicherman, 1991).

A reason with some subtlety may be that mutuals have a disadvantage and hence may be less efficient is that a life insurer cannot issue mutual annuities or disability insurance as paying policyholder dividends to this business makes no sense.

15 As mutuals do not issue stock, there is by definition no capital market (Cole et al., 1995) via which to monitor them. 
On the plus side for mutuals their lapses are no doubt lower - but this is minor as opposed to the above. As well mutual executives are compensated at considerably lower levels than are those of stocks (Mayers, Smith, 1992). As seen in the outcomes below this may be an overriding element in the determination of mutual versus stock LIC efficiency.

Notwithstanding these advantages, given both 1) the number and degree of disadvantages that mutuals have regarding efficiency as displayed in the previous and 2) from the results of studies comparing the two as illustrated below it is possible to conclude that without high executive compensation at the very least mutual LICs are not more efficient than are stocks.

\section{Results of Studies and Discussion}

As explained in the literature review there have been only twenty-six truly different studies observed that actually compare the efficiency of stock life insurance companies to that of mutuals along with just eighteen truly distinct papers seen that in reality contrast the efficiency of takaful/sharia life insurers with that of conventional entities.

Table 2 shows details of all of said research found that truly compare the efficiency of stock LICs with that of mutuals. ${ }^{16}$

When inspecting the papers one feature observed is that five have the problem that they do not separate life from general insurance. ${ }^{17}$ Regardless the overall results are that of the twentysix truly dissimilar studies seen that contrast the efficiency of the two, stocks are appraised to be more efficient in five, mutuals more efficient in seven and the efficiency of the two appear equal in fourteen. Additionally for the four readings that not considering efficiency per se, it is evaluated that stocks perform better in one, mutuals better in two and the stocks and mutuals look to do equally well in the other.

Table 3 depicts details of all of the aforementioned research seen that truly compare the efficiency of conventional LICs to that of takafuls.

\footnotetext{
${ }^{16}$ Fuentes, Grifell-Tatjé, Perelman (2005), which only has five mutual company data points versus 422 stock data points, is not included.

17 Treating life insurance and general insurance as one may be a deficiency in that the two industries are inherently distinct for example 1) general insurance claims are repeatable whereas with life insurance this is mostly not true; 2) a substantial part of life business is annuities which involves payment without the occurrence of a contingent event while this type of payment is much smaller for general insurance; 3 ) life insurance tends to be long term whereas general tends to be short term and 4) the regulations, capital requirements, etcetera of the two are (vastly) diverse.
} 


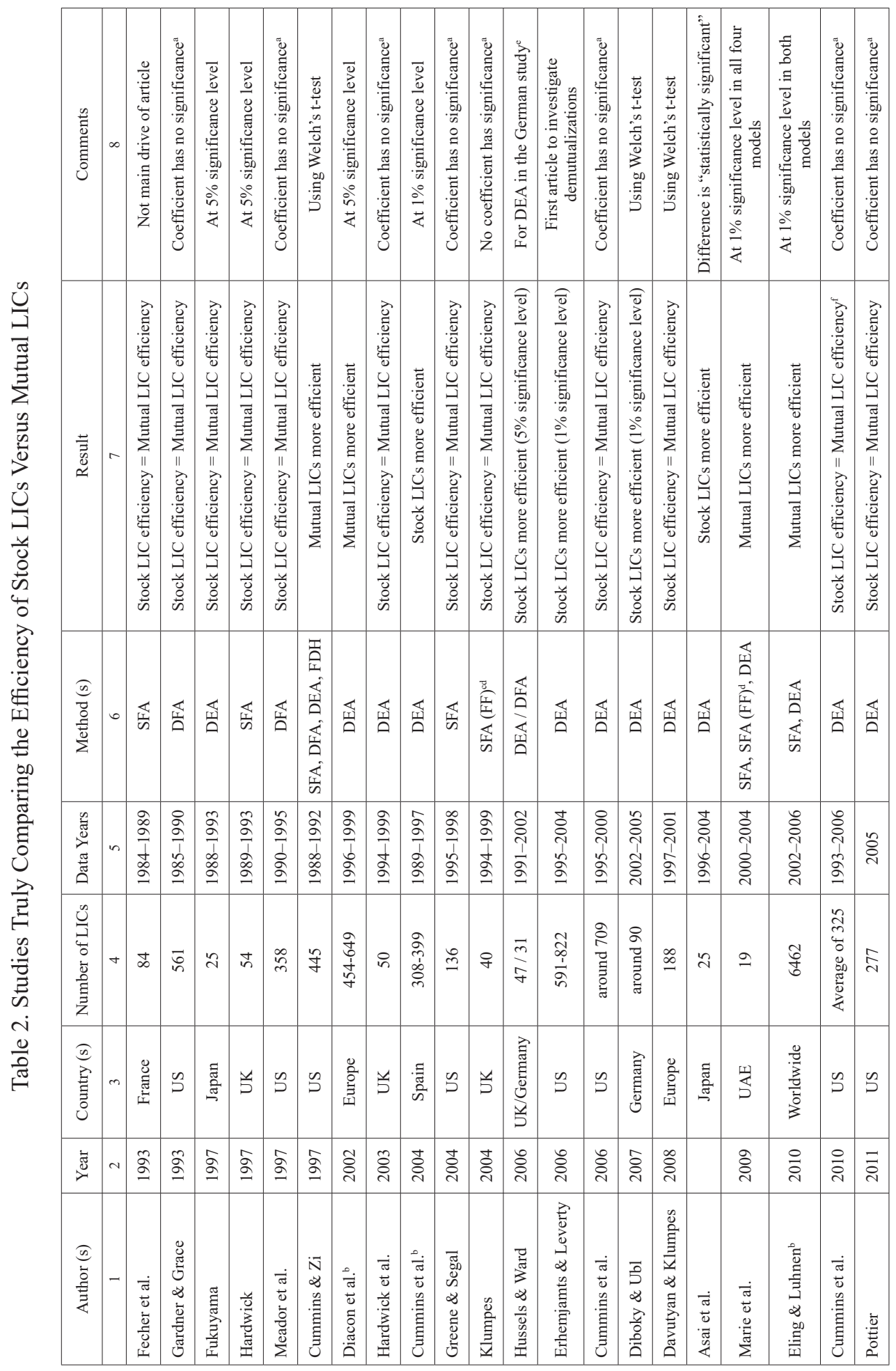




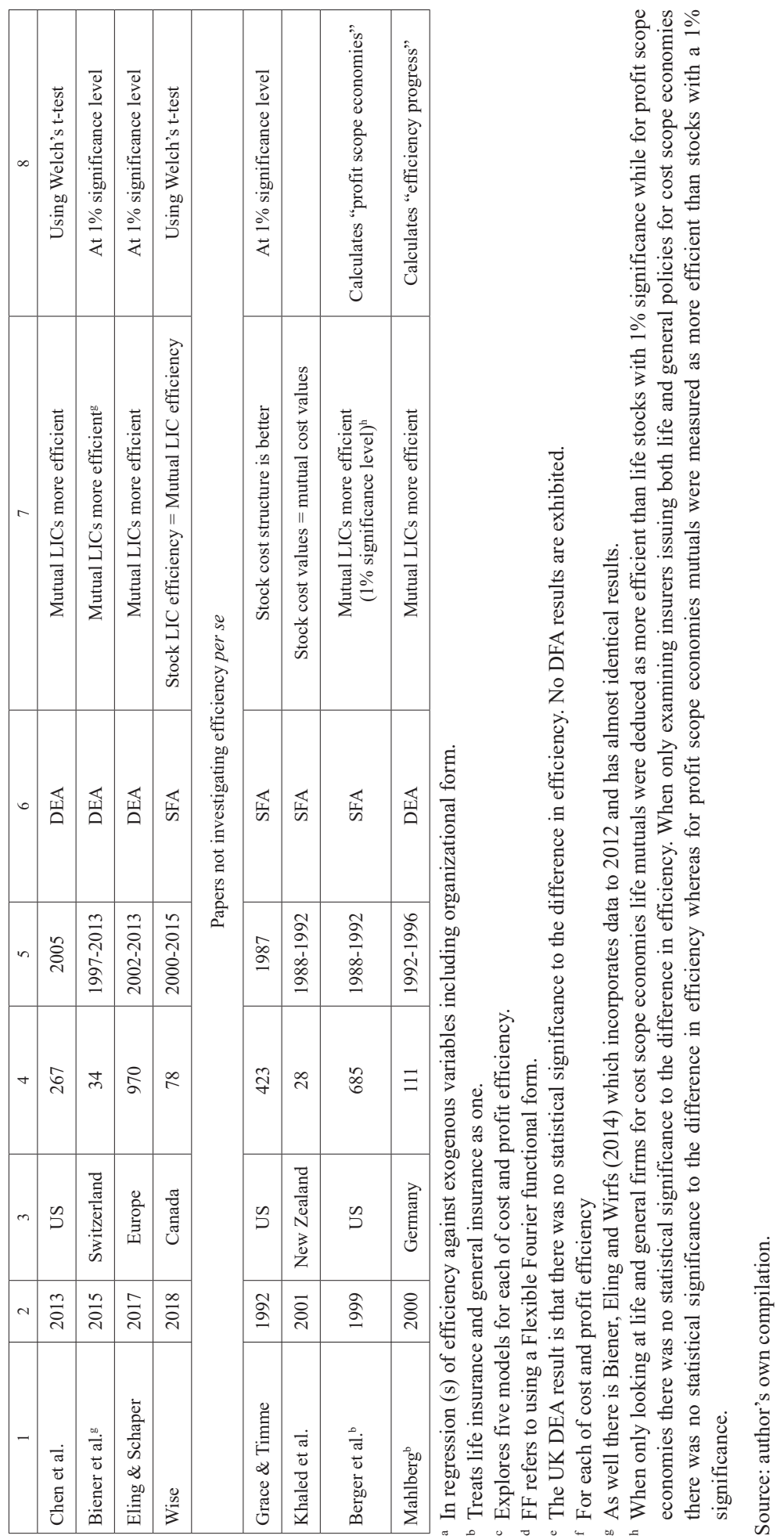




\begin{tabular}{|c|c|c|c|c|c|c|c|c|c|c|c|}
\hline $\begin{array}{l}\stackrel{0}{\Xi} \\
\text { : } \\
\text { : }\end{array}$ & $\infty$ & 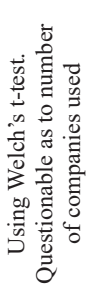 & 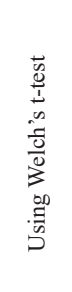 & 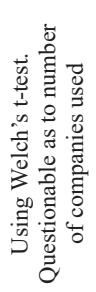 & 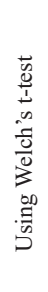 & & 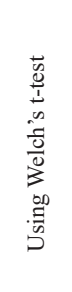 & 0 & 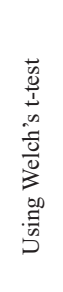 & & 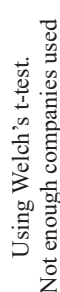 \\
\hline 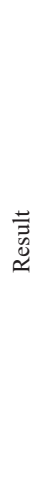 & - & 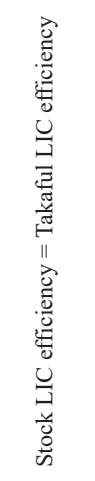 & 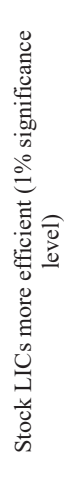 & 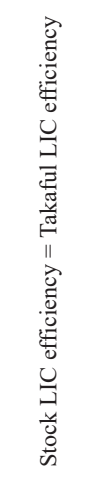 & 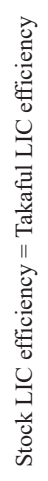 & م & 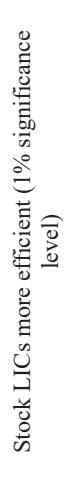 & 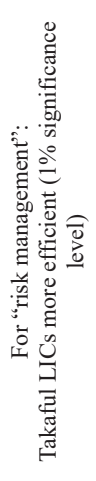 & 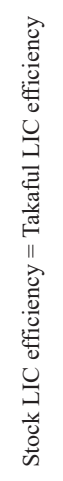 & 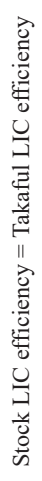 & 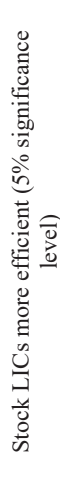 \\
\hline 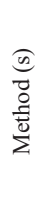 & o & 嵌 & 嵌 & 嵌 & 㟧 & 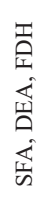 & 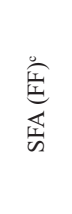 & 峲 & 峲 & 嵌 & 㟧 \\
\hline 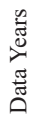 & n & 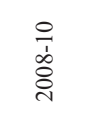 & $\begin{array}{l}\text { oे } \\
\text { +े } \\
\text { ه্ }\end{array}$ & $\begin{array}{l}\bar{\prime} \\
\text { ᄋें }\end{array}$ & 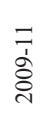 & 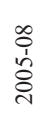 & $\begin{array}{l}\stackrel{\circ}{1} \\
\text { ல̊̀ } \\
\end{array}$ & $\begin{array}{l}\hat{0} \\
\text { ஸे } \\
\text { ¿ें }\end{array}$ & $\begin{array}{l}\overline{1} \\
\text { ᄋें } \\
\text { in }\end{array}$ & $\begin{array}{l}\frac{d}{d} \\
\text { 离 }\end{array}$ & 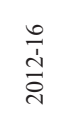 \\
\hline 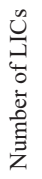 & ナ & $\simeq$ & $\stackrel{\infty}{\longrightarrow}$ & $\stackrel{m}{=}$ & $\stackrel{\sim}{\sim}$ & m & 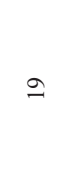 & ㄱ. & $\cong$ & $\stackrel{\infty}{\sim}$ & $\infty$ \\
\hline $\begin{array}{l}\text { त्ञ } \\
\text { 焉 } \\
0 \\
0\end{array}$ & m & 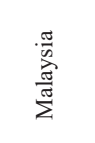 & 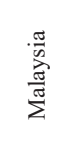 & 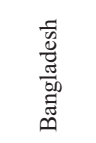 & 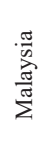 & 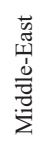 & 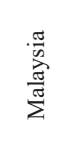 & 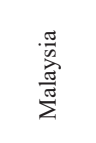 & 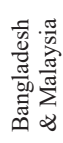 & 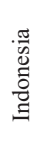 & 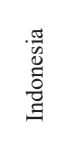 \\
\hline 荧 & N & $\stackrel{\sim}{\vec{\sim}}$ & $\stackrel{m}{\vec{N}}$ & $\stackrel{m}{\vec{N}}$ & $\stackrel{m}{\vec{\sim}}$ & $\stackrel{n}{\vec{\alpha}}$ & $\underset{\sim}{\stackrel{\sim}{*}}$ & $\underset{⿱ 亠}{\stackrel{\Delta}{*}}$ & $\stackrel{n}{\stackrel{n}{N}}$ & $\stackrel{\vec{i}}{\vec{i}}$ & $\overrightarrow{\tilde{N}}$ \\
\hline 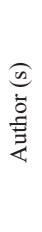 & - & 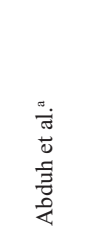 & 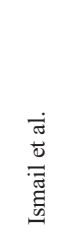 & 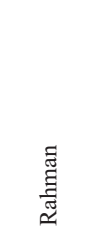 & 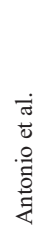 & 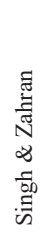 & 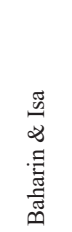 & 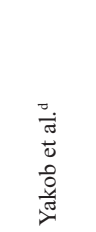 & 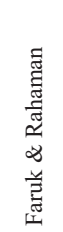 & 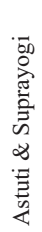 & 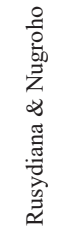 \\
\hline
\end{tabular}




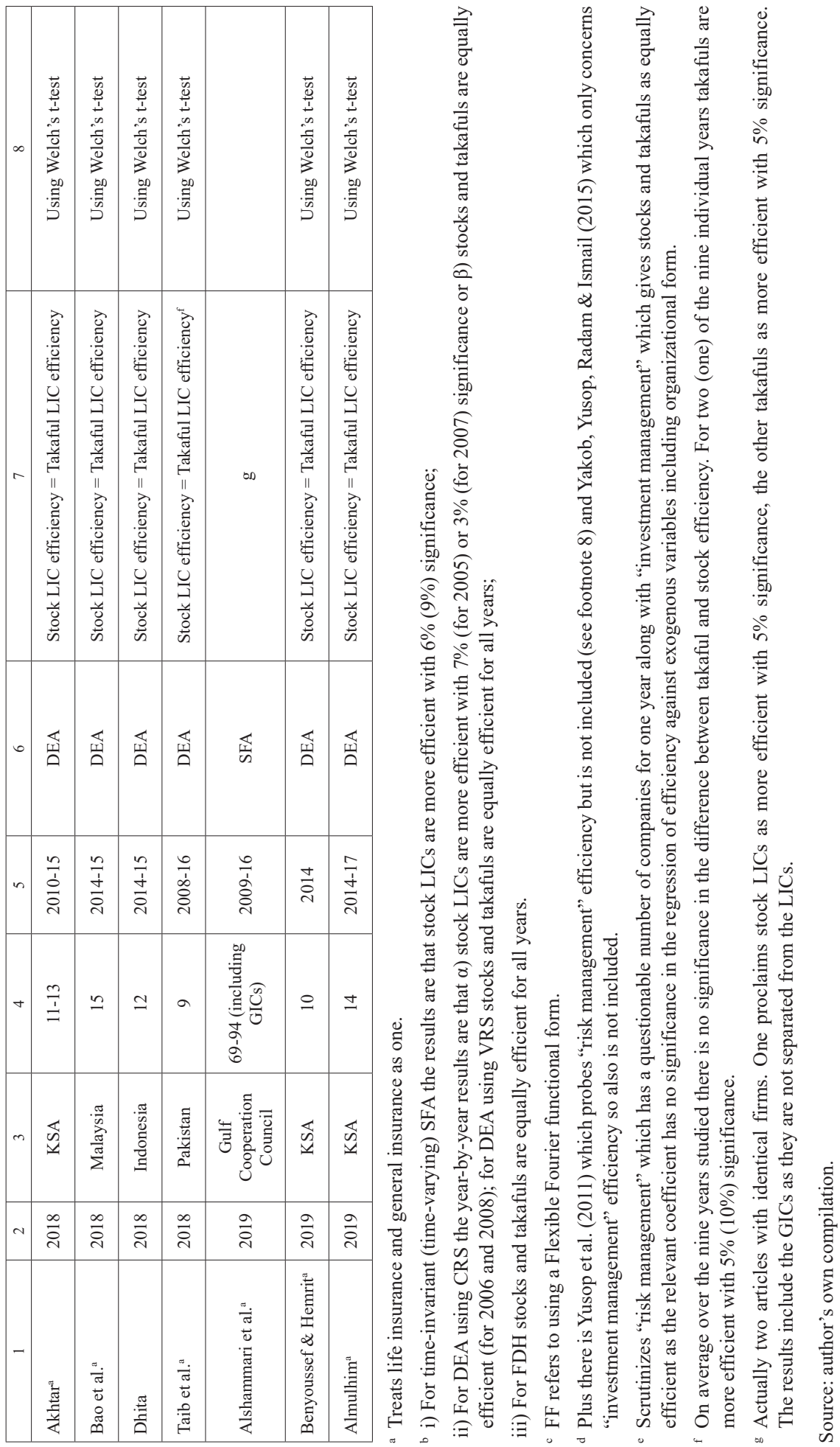


When looking at the eighteen papers one characteristic found is that seven have the flaw that they do not separate life from general insurance. Additionally four have the shortcoming of employing DEA with not enough entities (see footnote 9). Regardless the overall results are that of the eighteen ${ }^{18}$ truly disparate studies observed that contrast the efficiency of the two, conventional institutions are declared to be more efficient in five, takafuls more efficient in two and the efficiency of the two appear equal in eleven.

A trait of the outcomes as to the mutuals is that they tend to show that they are more efficient than the stock LICs, especially for the more recent studies. This is not in agreement with the theory as seen in Section 4, except for the aspect of executive compensation. Such compensation has been increasing recently. For example from January 2009 to December 2018 in the United States the median of non-executive pay increased at an annual compound rate of about $2 \%$ per year while CEO pay increased from a range of about 5 to $8 \% .{ }^{19}$ From 1978 to 2016 CEO pay increased by as much as $937 \%$ while that of a typical worker improved by only about $11 \% .{ }^{20}$ Hence this may be a clear indication that payments to executives in LICs are now getting too large as without such increases 1) stocks would seem to be more efficient than mutuals and 2) the resulting efficiency of stock LICs has the potential to seriously hurt the economy as portrayed in the foregoing.

The above demonstrates that mutuals are growing in importance and indicates that mutuals would seem to be less efficient than stocks life insurers if the latter did not pay such large executive compensations. Therefore when only considering insurance operations itself monitoring mutual efficiency still seems prudent. Plus it should be remarked that many of the stocks have demutualized comparatively recently, accordingly they still encompass some attributes of the relative inefficiency of mutuals as described in Section 4, e.g. higher administration costs associated with paying policyholder dividends and checking or changing the dividend scale. Therefore, if anything, this further emphasizes the possible inefficiency of mutuals as opposed to stocks. Another paper that advances the same notions is O. Erhemjamts and J.T. Leverty (2010) which deduces that full demutualization is preferable to partial as the former leads to both greater efficiency and ability to acquire capital.

\footnotetext{
18 There are also some papers that do not have a reasonable number of takafuls (besides what has been shown prior). These are Khan and Noreen (2014) with only two takaful of five LICs, Janjua and Akmal (2015) with only two of four, Jedidia and Medhioub (2015) with only two or three of twenty-one LICs and Abbas, Khan, Abbas and Mahmood (2018) with only two of five.

19 For companies in the S\&P 400 the median CEO increase was 5\%, for the S\&P 500 it was $4.6 \%$ and for the S\&P 600 7.7\% (Roe, Papadopoulos, 2019).

${ }^{20}$ The CEO increase was $807 \%$ (937\%) when including stock options granted (realized) (Karabell, 2018).
} 
Takafuls appear to be less efficient than conventional LICs. This emphasizes the concept of large executive pay affecting the efficiency of stock life companies as such remuneration does not exist in takafuls. Additionally as takafuls are rapidly becoming more prominent in the life insurance industry it would appear necessary to ensure their efficiency.

\section{Conclusions and Further Research}

As demonstrated in the preceding sections the life insurance industry is important to national economies so having a viable and sustainable life insurance industry is vital to the health of national economies. Also as discussed earlier several papers affirm that the efficiency of a life insurer can affect their profits and hence viability; examples being W.H. Greene and D. Segal (2004), M.Z.A. Karim and C. Jhantasana (2005), B. Liu (2007), A.L. Alhassan and G.K. Addison (2013) and W. Wise (2018). Thus it appears well established that inefficiency can have a negative influence on a nation's life industry. Therefore, as mutuals are (still) a substantial proportion of several of the world's largest life insurance industries as well as the global life industry, having mutuals be inefficient can be exceedingly negative.

In addition it is obvious that in theory stocks should be more efficient than mutuals due to reasons such as greater difficulty raising capital, higher administration costs, extra complexity controlling management plus the other problems illustrated in Section 4. However stock LICs appear to be less efficient in the more recent studies and the reason could very well be executive compensation that is too hefty. Perhaps such compensation should be scrutinized with company efficiency in mind.

Mutuals are increasing in importance worldwide and in theory look to be less efficient. The fact that mutuals are measured as more efficient than stocks in more, especially recent, studies is possibly attributable to the facts that 1) many stock companies have demutualized recently meaning that they still have many of the (at least theoretically) inherently inefficient aspects of mutuals within and 2) stock companies may be paying oversized executive compensation. Accordingly it would seem that, when only taking into account insurance operations itself, it is paramount to at least monitor if not put forth some effort to improve the efficiency of mutuals. This insight is buttressed by the fact that for the research comparing conventional LICs to takafuls, a larger number conclude that the former are more efficient.

There are several potential areas for further research regarding the efficiency of mutuals/ takafuls contrasted with stocks/conventionals. Perhaps the most crucial possibility is that of profit efficiency. Only three of the forty-four papers that compare the efficiency of mutuals/ 
takafuls to that of stocks/conventionals estimate profit efficiency. Profit efficiency might be seen as more essential than cost efficiency for example A.N. Berger, D. Hancock and D.B. Humphrey (1993) states that profit efficiency may reduce problems associated with misspecification and mismeasurement" and it "allows the researcher to pinpoint better the sources of inefficiency." 21 Furthermore profit efficiency is more general and includes cost efficiency (Akhavein, Berger, Humphrey, 1997, p. 96) and it may be that "[i]n studying firm performance, profit maximization is superior to cost minimization" (Berger, Mester, 2003, p. 67).

Other prospective further research includes investigating allocative efficiency in greater detail. Of the twenty-four papers using input prices only ten show allocative efficiency results. To highlight this shortcoming of the eleven studies using input prices published after 2007 only four display allocative efficiency results.

Further research can also be undertaken with respect to the functional forms used to determine life insurer efficiency. For example the four works that use both SFA and DEA do illustrate a comparison of the overall efficiency scores of mutuals/takafuls against stocks/ conventionals but none show a company-by-company comparison which has the potential to be of greater use. It also appears clear that more papers should employ both SFA and DEA (as only four of the forty-four do) and compare the results derived as it is possible that they will differ significantly. Additionally more methods, such as DFA and FDH, might be used with comparisons of results.

An insurance industry that is well developed and evolved makes available long term funds for every economy and hence is a windfall for economic development (Santhimol, Sanju, 2018). A life insurance industry that is sound and performs well is of great value to all elements of an economy, including consumers, producers and insurance firm stockholders (Bikker, 2012). The results from Section 5 fate that seemingly apart from the element of executive compensation, mutuals/takafuls are not more efficient than stock and conventional life insurers. As inefficiency can lead to dire economic consequences it seems imperative to determine or acknowledge why mutuals are less efficient and apply ideas designed to improve their efficiency.

\footnotetext{
21 The emphasis is in the original.
} 


\section{References}

Abbas, M., Khan, A.B., Abbas, S., Mahmood, Z. (2018). Determinants of Cost Efficiency of Takaful and Conventional Insurance Firms of Pakistan. Review of Economics and Development Studies, 4 (2), 331-340. DOI: 10.26710/reads.v4i2.418.

Abdou, H., Ali, K., Lister, R. (2014). A comparative study of Takaful and conventional insurance: empirical evidence from the Malaysian market. Insurance Markets and Companies: Analyses and Actuarial Computations, 4 (1), 23-35.

Abduh, M., Omar, M.A., Tarmizi, R.M. (2012). The Performance of Insurance Industry in Malaysia: Islamic vis-à-vis Conventional Insurance. Journal of Islamic Banking and Finance, 29 (4), 40-49.

Akhavein, J.D., Berger, A.N., Humphrey, D.B. (1997). The Effects of Megamergers on Efficiency and Prices: Evidence from a Bank Profit Function. Review of Industrial Organization, 12 (1), 95-139.

Akhtar, M.H. (2018). Performance analysis of Takaful and Conventional Insurance Companies in Saudi Arabia. Benchmarking: An International Journal, 25 (2), 677-695. DOI: 10.1108/BIJ-01-2017-0018.

Al-Amri, K., Hossain, M.Z. (2015). A survey of the Islamic insurance literature - takaful. Insurance Markets and Companies: Analyses and Actuarial Computations, 6 (1), 53-61.

Alam, K. (2015, September 7). Pakistan's Islamic insurance industry landscape set for makeover. The Express Tribune (Business). Retrieved from: https://tribune.com.pk/story/951858/ regulatory-ease-pakistans-islamic-insurance-industry-landscape-set-for-makeover.

Alhassan, A.L., Addison, G.K. (2013). Market Structure, Efficiency and Performance: Empirical Evidence from the Ghanaian Life Insurance Market. Paper presented at the First University of Ghana Business School Conference and Development in Africa, Accra, Ghana held April 8-9, 2013.

Almulhim, T. (2019). Analysis of Takaful vs. Conventional insurance firms' efficiency: Twostage DEA of Saudi Arabia's insurance market. Cogent Business \& Management, 6 (1). DOI: $10.1080 / 23311975.2019 .1633807$.

Alshammari, A.A., Alhabshi, S.M. b. S.J., Saiti, B. (2019). The impact of competition on cost efficiency of insurance and takaful sectors: Evidence from GCC markets based on the Stochastic Frontier Analysis. Research in International Business and Finance, 47, 410-427. DOI: 10.1016/j.ribaf.2018.09.003.

Alshammari, A.A., Alhabshi, S.M. b. S.J., Saiti, B. (2019). The impact of oil prices and the financial market on cost efficiency in the insurance and Takaful sectors: Evidence from a stochastic frontier analysis. Economic systems, 43 (3-4). DOI: 10.1016/j.ecosys.2019.100716. 
Antonio, M.S., Ali, M.M., Akbar, N. (2013). A comparative analysis of the efficiency of takaful and conventional insurance in Malaysia. International Journal of Excellence in Islamic Banking and Finance, 3 (1), 1-13.

Aoba, N. (2006). Efficiency in the Japanese Life Insurance Industry: Dramatic Change. Paper presented at the American Risk and Insurance Association 2006 Annual Meeting, Washington, DC held August 6-9, 2006.

Asai, Y., Noriyoshi, Y., Kei, T., Junya, O. The Efficiency and Productivity of Life Insurance Industry in Japan. Retrieved from: http://s3.amazonaws.com/zanran_storage/nccu.edu.tw/ ContentPages/18221496.pdf.

Association of Mutual Insurers and Insurance Cooperatives in Europe, The (AMICE) and International Cooperative and Mutual Insurance Federation, The (ICMIF). (2018). Facts and figures: Mutual and cooperative insurance in Europe Vol 2. Brussels, Belgium and Cheshire, UK: AMICE aisbl and ICMIF.

Astuti, Y.F., Suprayogi, N. (2017). Differences in Efficiency of Shariah and Conventional Life Insurance Companies in Indonesia Using the Data Envelopment Analysis (DEA) Method (Perbedaan Efisiensi Perusahaan Asuransi Jiwa Syariah dan Konvensional di Indonesia Dengan Metode Data Envelopment Analysis (DEA)). Jurnal Ekonomi Syariah Teori dan Terapan (The Journal of Theoretical and Applied Sharia Economics), 4 (8), 668-683.

Baharin, R., Isa, Z. (2014). The Efficiency of Life Insurance and Family Takaful in Malaysia: Relative Efficiency Using the Stochastic Cost Frontier Analysis. Insurance and Takaful Journal, 6, 25-35.

Bank Negara Malaysia (Central Bank of Malaysia) (2016). Financial Stability and Payment Systems Report 2015. Kuala Lumpur, Malaysia: Bank Negara Malaysia.

Bank of England (2018). List of EEA Authorised Insurers as Compiled by the Bank of England as at 01 October 2018. London, UK: Bank of England. Retrieved from: https://www. bankofengland.co.uk/-/media/boe/files/prudential-regulation/authorisations/which-firmsdoes-the-pra-regulate/2018/list-of-authorised-insurers/list-of-eea-authorised-insurersoct-2018.pdf.

Banks Around the World (2018). Top Insurance Companies in Asia. Retrieved from: http:// www.relbanks.com/top-insurance-companies/asia.

Bao, N.J., Ramlan, R., Mohamad, F., Yassin, A.M. (2018). Performance of Malaysian Insurance Companies Using Data Envelopment Analysis. Indonesian Journal of Electrical Engineering and Computer Science, 11 (3), 1147-1151. DOI: 10.11591/ijeecs.v11.i3.pp1147-1151.

Bauer, P.W., Berger, A.N., Ferrier, G.D., Humphrey, D.B. (1998). Consistency Conditions for Regulatory Analysis of Financial Institutions: A Comparison of Frontier Efficiency Methods. Journal of Economics and Business, 50 (2), 85-114. 
Benyoussef, S., Hemrit, W. (2019). Measuring the relative efficiency of insurance companies in Saudi Arabia: The case study of Takaful vs cooperative industries. Cogent Economics \& Finance, 7 (1). DOI: 10.1080/23322039.2019.1590818.

Berger, A.N., Cummins, J.D., Weiss, M.A., Zi, H. (1999). Conglomeration versus Strategic Focus: Evidence from the Insurance Industry. The Wharton Financial Institutions Center, University of Pennsylvania, Philadelphia, PA, Working Paper 99-29-B.

Berger, A.N., Hancock, D., Humphrey, D.B. (1993). Bank efficiency derived from the profit function. Journal of Banking \& Finance, 17 (2-3), 317-347.

Berger, A.N., Mester, L.J. (2003). Explaining the dramatic changes in performance of US banks: technological change, deregulation, and dynamic changes in competition. Journal of Financial Intermediation, 12 (1), 57-95.

Biener, C., Eling, M., Wirfs, J.H. (2014). The Determinants of Efficiency and Productivity in the Swiss Insurance Industry. Paper presented at the 41st Seminar of the European Group of Risk and Insurance Economists, St. Gallen, Switzerland held September 15-17.

Biener, C., Eling, M., Wirfs, J.H. (2015). The Determinants of Efficiency and Productivity in the Swiss Insurance Industry. School of Finance, Institute of Insurance Economics (I.VWHSG), University of St. Gallen, St. Gallen, Switzerland, Working Paper on Finance No. $2015 / 2$.

Bikker, J.A. (2012). Performance of the life insurance industry under pressure: efficiency, competition and consolidation. De Nederlandsche Bank NV, Amsterdam, The Netherlands, Working Paper No. 357.

Boose, M.A. (1990). Agency Theory and Alternative Predictions for Life Insurers: An Empirical Test. The Journal of Risk and Insurance, 57 (3), 499-518.

Carson, J.M., Forster, M.D., McNamara, M.J. (1998). Changes in Ownership Structure: Theory and Evidence from Life Insurer Demutualizations. Journal of Insurance Issues, 21 (1), $1-22$.

Chen, L., Eckles, D.L., Pottier, S.W. (2013). Ownership Form and Efficiency: The Coexistence of Stock and Mutual Life Insurers. The Journal of Insurance Issues, 36 (2), 121-148.

CISION PR Newswire (Research and Markets) (2018, September 10). Global Takaful Market 2017-2018 \& 2023. Retrieved from: https://www.prnewswire.com/news-releases/globaltakaful-market-2017-2018--2023-300709652.html.

Cole, C.S., McNamara, M.J., Wells, B.P. (1995). Demutualizations and Free Cash Flow. Journal of Insurance Issues, 18 (1), 37-56.

Cooper, W.W., Li, S., Seiford, L.M., Thrall, R.M., Zhu, J. (2001). Sensitivity and stability analysis in DEA: Some recent developments. Journal of Productivity Analysis, 15 (3), 217-246.

Cummins, J.D., Eckles, D.L., Zi, H. (2006). Exporting best practices: Are foreign-owned insurers more efficient in the US Life Insurance Market? Working paper. 
Cummins, J.D., Rubio-Misas, M., Vencappa, D. (2017). Competition, Efficiency and Soundness in European Life Insurance Markets. Journal of Financial Stability, 28, 66-78. DOI: 10.1016/j.jfs.2016.11.007.

Cummins, J.D., Rubio-Misas, M., Zi, H. (2004). The effect of organizational structure on efficiency: Evidence from the Spanish insurance industry. Journal of Banking \& Finance, 28 (12), 3113-3150. DOI: 10.1016/j.jbankfin.2004.05.004.

Cummins, J.D., Zi, H. (1997). Measuring Cost Efficiency in the U.S. Life Insurance Industry: Econometric and Mathematical Programming Approaches. The Wharton Financial Institutions Center, University of Pennsylvania, Philadelphia, PA, Working Paper 97-03.

Cummins, J.D., Weiss, M.A., Xie, X., Zi, H. (2010). Economies of scope in financial services: A DEA efficiency analysis of the US insurance industry. Journal of Banking \& Finance, 34 (7), 1525-1539. DOI: 10.1016/j.jbankfin.2010.02.025.

Davutyan, N., Klumpes, P.J.M. (2008). Consolidation and Efficiency in the Major European Insurance Markets: A Non Discretionary Inputs Approach. Paper presented at a conference on the Uses of Frontier Efficiency Methodologies for Performance Measurement in the Financial Services Sector, Imperial College Business School, London, UK held July 4-5.

Dhita, A.G. (2018). Efficiency of Company Financial Performance Conventional Insurance and Sharia Insurance with DEA (Data Envelopment Analysis) Approach 2014 and 2015 (Efisiensi Kinerja Keuangan Perusahaan Asuransi Konvensional dan Asuransi Syariah Dengan Pendekatan DEA (Data Envelopment Analysis) Tahun 2014 dan 2015). Faculty of Economics, Indonesian Islamic University, Yogyakarta, Indonesia.

Diacon, S.R., Starkey, K., O’Brien, C. (2002). Size and Efficiency in European Long-term Insurance Companies: An International Comparison. The Geneva Papers on Risk and Insurance-Issues and Practice, 27 (3), 444-466. DOI: 10.1111/1468-0440.00184.

Diboky, F., Ubl, E. (2007). Ownership and Efficiency in the German Life Insurance Market: A DEA Bootstrap Approach. Department of Finance, University of Vienna, Vienna, Austria, Working Paper Series.

Dyson, R.G., Allen, R., Camanho, A.S., Podinovski, V.V., Sarrico, C.S., Shale, E.A. (2001). Pitfalls and protocols in DEA. European Journal of Operational Research, 132 (2), 245-259.

Eling, M., Luhnen, M. (2010). Efficiency in the international insurance industry: A cross-country comparison. Journal of Banking \& Finance, 34 (7), 1497-1509. DOI: 10.1016/j.jbankfin.2009.08.026.

Eling, M., Schaper, P. (2017). Under pressure: how the business environment affects productivity and efficiency of European life insurance companies. European Journal of Operational Research, 258 (3), 1082-1094. DOI: 10.1016/j.ejor.2016.08.070.

Erhemjamts, O., Leverty, J.T. (2006). Efficiency changes around US life insurer demutualizations. Working Paper. 
Erhemjamts, O., Leverty, J.T. (2010). The Demise of the Mutual Organizational Form: An Investigation of the Life Insurance Industry. Journal of Money, Credit and Banking, 42 (6), 1011-1036.

Fama, E.F. (1980). Agency Problems and the Theory of the Firm. Journal of Political Economy, 88 (2), 288-307.

Fama, E.F., Jensen, M.C. (1983). Separation of Ownership and Control. The Journal of Law \& Economics, 26 (2), 301-325.

Faruk, M.O., Rahaman, A. (2015). Measuring Efficiency of Conventional Life Insurance Companies in Bangladesh and Takaful Life Insurance Companies in Malaysia: A Non-Parametric Approach. Management Studies and Economic Systems, 2 (2), 129-144.

Fecher, F., Kessler, D., Perelman, S., Pestieau, P. (1993). Productive performance of the French Insurance Industry. Journal of Productivity Analysis, 4 (1/2), 77-93. DOI: 10.1007/ BF01073467.

Fuentes, H., Grifell-Tatjé, E., Perelman, S. (2005). Product Specialization, Efficiency and Productivity Change in the Spanish Insurance Industry. Centre de Recherche en Economie Publique et de la Population (Research Center on Public and Population Economics), HEC-Management School, University of Liege, Liege, Belgium, Working Paper 0506.

Fukuyama, H. (1997). Investigating productive efficiency and productivity changes of Japanese life insurance companies. Pacific-Basin Finance Journal, 5 (4), 481-509. DOI: 10.1016/ S0927-538X(97)00016-4.

Gardner, L.A, Grace, M.F. (1993). X-Efficiency in the US life insurance industry. Journal of Banking \& Finance, 17 (2-3), 497-510. DOI: 10.1016/0378-4266(93)90048-I.

Grace, M.F., Klein, R.W., Phillips, R.D. (2003). Insurance Company Failures: Why Do They Cost So Much? The Wharton Financial Institutions Center, University of Pennsylvania, Philadelphia, PA, Working Paper 03-32.

Grace, M.F., Timme, S.G. (1992). An Examination of Cost Economies in the United States Life Insurance Industry. Journal of Risk and Insurance, 59 (1), 72-103.

Greene,W.H., Segal,D.(2004).Profitability andEfficiency in theU.S.LifeInsuranceIndustry.Journal of Productivity Analysis, 21 (3), 229-247. DOI: 10.1023/B:PROD.0000022092.70204. fa.

Hanif, J., Munir, Z. (2019). Life Insurance and Family Takaful in Pakistan. Lahore, Pakistan: The Pakistan Credit Rating Agency Limited. Retrieved from: http:/www.pacra.com.pk/ uploads/doc_report/Life.Ins_Presentation\%20-\%20Jun\%2019.pdf

Hansmann, H. (1985). The Organization of Insurance Companies: Mutual versus Stock. Journal of Law, Economics, \& Organization, 1 (1), 125-153.

Hardwick, P. (1997). Measuring cost efficiency in the UK life insurance industry. Applied Financial Economics, 7 (1), 37-44. 
Hardwick, P., Adams, M.B., Zou, H. (2003). Corporate Governance and Cost Efficiency in the United Kingdom Life Insurance Industry European Business Management School, Swansea, UK, Working Paper No. EBMS/2003/1.

Holzmüller, I. (2009). The United States RBC Standards, Solvency II and the Swiss Solvency Test: A Comparative Assessment. The Geneva Papers on Risk and Insurance Issues and Practice, 34 (1), 56-77.

Hussels, S., Ward, D.R. (2006). The Impact of Deregulation on the German and UK Life Insurance Markets: An Analysis of Efficiency and Productivity Between 1991-2002. Paper presented at the Dynamics of Insurance Markets: Structure, Conduct, and Performance in the 21st Century, A Journal of Banking and Finance Conference, Wharton School, University of Pennsylvania, Philadelphia, PA held May 4-5, 2006.

Insurance Edge Editor (in Insurance \& Reinsurance) (2019). Market Snapshot: French Banks Extend Footprint into Insurance Sector. Retrieved from: https://insurance-edge. net/2019/02/07/market-snapshot-french-banks-extend-footprint-into-insurance-sector.

Insurance Europe (2015). European Insurance - Key Facts August 2015. Brussels, Belgium: Insurance Europe aisbl.

International Cooperative and Mutual Insurance Federation, The (ICMIF) (2016a). Global Mutual Market Share 2014: The global insurance market share as held by mutual and cooperative insurers. Cheshire, UK: ICMIF.

International Cooperative and Mutual Insurance Federation, The (ICMIF) (2016b). Market InSights 2016: Europe. Cheshire, UK: ICMIF.

International Cooperative and Mutual Insurance Federation, The (ICMIF) (2016c). Market InSights 2016: UK. Cheshire, UK: ICMIF.

International Cooperative and Mutual Insurance Federation, The (ICMIF) (2017a). Global Mutual Market Share 2015: The global insurance market share as held by mutual and cooperative insurers. Cheshire, UK: ICMIF.

International Cooperative and Mutual Insurance Federation, The (ICMIF) (2017b). Sector news: China's regulator issues rules on information disclosure for mutual insurers. Cheshire, UK: ICMIF. Retrieved from: https://www.icmif.org/news/sector-news-china $\%$ E2\%80\%99sregulator-issues-rules-information-disclosure-mutual-insurers.

International Cooperative and Mutual Insurance Federation, The (ICMIF) (2019). Global Mutual Market Share 10: The Global Insurance Market Share Held by Mutual and Cooperative Insurers. Cheshire, UK: ICMIF.

Islamic Financial Services Board (IFSB) (2017). Islamic Financial Services Industry Stability Report 2017. Kuala Lumpur, Malaysia: IFSB.

Islamic Financial Services Board (IFSB) (2018). Islamic Financial Services Industry Stability Report 2018. Kuala Lumpur, Malaysia: IFSB. 
Ismail, N., Alhabshi, D.S.O., Bacha, O.I. (2011). Organizational Form and Efficiency: The Coexistence of Family Takaful and Life Insurance in Malaysia. Journal of Global Business and Economics, 3 (1), 122-137.

Ismail, N., Alhabshi, D.S.O., Bacha, O.I. (2013). Cost Efficiency and Investment Performance: Mutual and Stock Form in Malaysian Insurance Industry. Paper presented at the $15^{\text {th }}$ Malaysian Finance Association Conference, International Centre for Education in Islamic Finance, Kuala Lumpur, Malaysia held June 2-4.

Jaffer, S., Ismail, F., Noor, J., Unwin, L. (2010). Takaful (Islamic Insurance): Concept, Challenges, and Opportunities. Seattle, WA: Milliman, Incorporated.

Janjua, P.Z., Akmal, M. (2015). A Comparative Analysis of Economic Efficiency of Conventional and Islamic Insurance Industry in Pakistan. Pakistan Business Review, 17 (1), 21-44.

Jedidia, L.B., Medhioub, I. (2015). The Efficiency of Saudi Arabia Insurance Companies. International Journal of Management Sciences, 5 (3), 237-248.

Jeng, V., Lai, G.C., McNamara, M.J. (2007). Efficiency and Demutualization: Evidence from the U.S. Life Insurance Industry in the 1980s and 1990s. The Journal of Risk and Insurance, 74 (3), 683-711.

Jensen, M.C. (1986). Agency Costs of Free Cash Flow, Corporate Finance, and Takeovers. The American Economic Review, 76 (2), 323-329.

Jensen, M.C., Meckling, W.H. (1976). Theory of the firm: Managerial behavior, agency costs and ownership structure. Journal of Financial Economics, 3 (4), 305-360.

Karabell, S. (2018). Executive Compensation Is Out Of Control. What Now? Retrieved from: https://www.forbes.com/sites/shelliekarabell/2018/02/14/executive-compensation-is-outof-control-what-now/\#109bd0a6431f.

Karim, M.Z.A., Jhantasana, C. (2005). Cost Efficiency and Profitability in Thailand's Life Insurance Industry: A Stochastic Cost Frontier Approach. International Journal of Applied Econometrics and Quantitative Studies, 2 (4), 19-36.

Khaled, M., Adams, M.B., Pickford, M. (2001). Estimates of Scale and Scope Economies in the New Zealand Life Insurance Industry. The Manchester School, 69 (3), 327-349.

Khan, A., Noreen, U. (2014). Efficiency Measure of Insurance v/s Takaful Firms Using DEA Approach: A Case of Pakistan. Islamic Economic Studies, 22 (1), 139-158. DOI: $10.12816 / 0004133$.

Kim, H., Grace, M.F. (1995). Potential Ex Post Efficiency Gains of Insurance Company Mergers. Center for Risk Management and Insurance Research, Georgia State University, Atlanta, GA, Working Paper No. 95-4.

Klumpes, P.J.M. (2004). Performance Benchmarking in Financial Services: Evidence from the UK Life Insurance Industry. The Journal of Business, 77 (2), 257-273. DOI: $10.1086 / 381281$. 
Korea Life Insurance Association (2019). Report \& Statistics, Annual Statistics, 2018 Year, I. Summary of Life Insurance Business. Retrieved from: https://www.klia.or.kr/eng/reportStatistics/annualStatistics.do.

KPMG Siddharta Advisory (2016). Insurance in Indonesia: Opportunities in a Dynamic Market. Jakarta, Indonesia: KPMG Siddharta Advisory.

Lamm-Tennant, J., Starks, L.T. (1993). Stock Versus Mutual Ownership Structures: The Risk Implications. The Journal of Business, 66 (1), 29-46.

Life Insurance Association of Japan, The (LIAJ) (2015). Life Insurance Business in Japan 2014-15. Tokyo, Japan: LIAJ.

Life Insurance Association of Japan, The (LIAJ) (2017). Life Insurance Fact Book (2017). Tokyo, Japan: LIAJ.

Lim, J., Idris, M.F., Carissa, Y. (2010). History, Progress and Future Challenge of Islamic Insurance (Takaful) In Malaysia. Paper presented at the 2010 Oxford Business \& Economics Conference Program, St. Hugh's College, Oxford University, Oxford, UK, held June 28-29.

Liu, B. (2007). Empirical Research of the Market Structure, Efficiency and Performance of Life Insurance Industry in China. Industrial Economics Research, 2007 (4), 19-26. DOI: 10.13269/j.cnki.ier .2007.04.009.

Mahlberg, B. (2000). Efficiency Progress and Productivity Change in Germany's Insurance Industry (Technischer Fortschritt und Produktivitätsveränderungen in der deutschenVersicherungswirtschaft). Jahrbücher für Nationalökonomik und Statistik (Journal of Economics and Statistics), 220 (5), 565-591.

Maierbrugger, A. (2019, February 12). Morocco finally sets the stage for takaful industry. Gulf Times. Retrieved from: https:/www.gulf-times.com/story/621996/Morocco-finally-setsthe-stage-for-takaful-industr.

Mann, S.V., Sicherman, N.W. (1991). The Agency Costs of Free Cash Flow: Acquisition Activity and Equity Issues. The Journal of Business, 64 (2), 213-227.

Marie, A., Rao, A., Kashani, H. (2009). Cost Efficiency and Value Driver Analysis of Insurers in an Emerging Economy. Managerial and Decision Economics, 30 (4), 265-280. DOI: $10.1002 /$ mde. 1454 .

Mayers, D., Smith, C. (1981). Contractual Provisions, Organizational Structure, and Conflict Control in Insurance Markets. Journal of Business, 54 (3), 407-434.

Mayers, D., Smith, C. (1988). Ownership Structure across Lines of Property Casualty Insurance. Journal of Law and Economics, 31 (2), 351-78.

Mayers, D., Smith, C. (1992). Executive Compensation in the Life Insurance Industry. The Journal of Business, 65 (1), 51-74. 
Mayers, D., Smith, C. (1994). Managerial Discretion, Regulation, and Stock Insurer Ownership Structure. The Journal of Risk and Insurance, 61 (4), 638-655.

Meador, J.W., Ryan, Jr., H.E., Schellhorn, C.D. (1997). Product Focus versus Diversification: Estimates of X-Efficiency for the US Life Insurance Industry. The Wharton Financial Institutions Center, University of Pennsylvania, Philadelphia, PA, Working Paper 97-16.

Milliman (2017). Global Takaful Report: Market trends in family and general Takaful. Seattle, WA: Milliman, Incorporated.

National Association of Insurance Commissioners (NAIC) (2016). Life Insurance IndustryIndividual Company Data, Statistical Compilation of Annual Statement Information for Life/Health Insurance Companies in 2015. Washington, DC: NAIC.

O'Hara, M. (1981). Property rights and the financial firm. Journal of Law and Economics, 24 (2), 317-332.

Organization for Economic Co-operation and Development. Dataset: Balance sheet and income, Total Assets, Direct Insurer, 2012. Retrieved from: https://stats.oecd.org/Index. aspx?DatasetCode=INSIND.

Organization for Economic Co-operation and Development. Dataset: Balance sheet and income, Total Assets, Direct Insurer, 2013. Retrieved from: https://stats.oecd.org/Index. aspx?DatasetCode=INSIND.

Organization for Economic Co-operation and Development. Dataset: Balance sheet and income, Total Assets, Direct Insurer, 2014. Retrieved from: https://stats.oecd.org/Index. aspx? DatasetCode=INSIND.

Organization for Economic Co-operation and Development. Dataset: Balance sheet and income, Total Assets, Direct Insurer, 2015. Retrieved from: https://stats.oecd.org/Index. aspx?DatasetCode=INSIND.

Organization for Economic Co-operation and Development. Dataset: Business written in the reporting country, Business written in the reporting country, All undertakings $(=1+3)$, Gross premiums, Of which: Life, Direct business, Total. Retrieved from: https://stats.oecd. org/Index.aspx?DatasetCode=INSIND.

Organization for Economic Co-operation and Development. Dataset: Business written in the reporting country, Business written in the reporting country, All undertakings $(=1+3)$, Gross premiums, Of which: Non-Life, Direct business, Total. Retrieved from: https://stats. oecd.org/Index.aspx?DatasetCode=INSIND.

Oxford Business Group. Egypt's insurance sector posts strong growth in tough economic context. Retrieved from: https://oxfordbusinessgroup.com/overview/catching-sector-postsstrong-growth-tough-economic-context.

Pottier, S.W. (2011). Life insurer efficiency and state regulation: evidence of optimal firm behaviour. Journal of Regulatory Economics, 39 (2), 169-93. DOI: 10.1007/s11149-0109139-7. 
PricewaterhouseCoopers (2008). Takaful: Growth opportunities in a dynamic market. London, UK: PricewaterhouseCoopers.

Rahman, M.A. (2013). Comparative Study on the Efficiency of Bangladeshi Conventional and Islamic Life Insurance Industry: A Non-Parametric Approach. Asian Business Review, 2 (3), 88-99. DOI: 10.18034/abr.v3i4.284.

Roe, J., Papadopoulos, K. (2019). 2019 U.S. Executive Compensation Trends. Harvard Law School Forum on Corporate Governance. Retrieved from: https://corpgov.law.harvard. edu/2019/04/16/2019-u-s-executive-compensation-trends.

Rusydiana, A.S., Nugroho, T. (2017). Measuring Efficiency of Life Insurance Institution in Indonesia: Data Envelopment Analysis Approach. Global Review of Islamic Economics and Business, 5 (1), 12-24.

Saad, N.M., Idris, N.E.H. (2011). Efficiency of Life Insurance Companies in Malaysia and Brunei: A Comparative Analysis. International Journal of Humanities and Social Science, 1 (3), 111-122.

Saad, N.M., Majid, M.S.A., Yusof, R.M., Duasa, J., Rahman, A.R.A. (2006). Measuring Efficiency of Insurance and Takaful Companies in Malaysia Using Data Envelopment Analysis (DEA). Review of Islamic Economics, 10 (2), 5-26.

Santhimol, M.C., Shaju, M.J. (2018). Concentration, Competition, Profitability and Performance Efficiency of Select Life Insurers in Kerala. International Journal of Research in Management, Economics and Commerce, 8 (3), 55-61.

Schiff, D. (1998). The Big Fix: Mutual Insurance Holding Companies. Schiff's Insurance Observer, $10(1 \& 2)$.

Shafique, M.N., Ahmad, N., Ahmad, H., Adil, M.Y. (2015). A Comparative Study of the Efficiency of Takaful and Conventional Insurance in Pakistan. International Journal of Accounting Research, 2 (5), 1-7.

Simmons, J., Siddiqui, A. (2011, February 14). Canada: "Takaful" - Islamic Insurance. Mondaq Limited. Retrieved from: http://www.mondaq.com/canada/x/120566/Insurance/ Takaful+Islamic+Insurance.

Singh, A., Zahran, Z. (2013). A Comparison of the Efficiency of Islamic and Conventional Insurers. Towers Watson Perspectives, 2013. New York, NY: Towers Watson.

Singh, H. (2018). Malaysia's takaful growth outpacing conventional insurance. Islamic Finance. Retrieved from: https://themalaysianreserve.com/2018/02/05/malaysias-takafulgrowth-outpacing-conventional-insurance.

Statistics Portal, The (2020a). Number of mutual life insurance companies in the United States from 1950 to 2018. Hamburg, Germany: Statista. Retrieved from: https://www.statista. com/statistics/194334/number-of-mutual-life-insurance-companies-in-the-us-since-1950. 
Statistics Portal, The (2020b). Development in the total number of life insurance companies in the United States from 1950 to 2018. Hamburg, Germany: Statista. Retrieved from: https:// www.statista.com/statistics/194335/total-number-of-life-insurance-companies-in-the-us.

Swiss Reinsurance Company Limited (2015). World insurance in 2014: Back to life. sigma No4/2015. Zurich, Switzerland: Swiss Reinsurance Company Limited Economic Research \& Consulting.

Swiss Reinsurance Company Limited (2016). World insurance in 2015: Steady growth amid regional disparities. sigma No. 3/2016. Zurich, Switzerland: Swiss Reinsurance Company Limited Economic Research \& Consulting.

Swiss Reinsurance Company Limited (2017). World insurance in 2016: The China growth engine steams ahead. sigma No. 3/2017. Zurich, Switzerland: Swiss Re Institute Swiss Re Management Limited.

Swiss Reinsurance Company Limited (2018). World insurance in 2017: Solid, but mature life markets weigh on growth. sigma No3/2018. Zurich, Switzerland: Swiss Re Institute Swiss Re Management Limited.

Swiss Reinsurance Company Limited. (2019). World insurance: the great pivot east continues. sigma No. 3/2019. Zurich, Switzerland: Swiss Re Management Limited Swiss Re Institute.

Taib, C.A., Ashraf, M.S., Razimi, M.S.B.A. (2018). Technical, Pure Technical and Scale Efficiency: A Non-Parametric Approach of Pakistan's Insurance and Takaful Industry. Academy of Accounting and Financial Studies Journal, 22 (SI).

Terzo, G. (2019, April 14). Bitcoin Disrupts France’s Massive \$2.5 Trillion Life Insurance Market. Cryptocurrency News. Retrieved from: https://www.ccn.com/bitcoin-disruptstrillion-french-life-insurance.

Thanassoulis, E., Portel, M.C.S., Despic, O. (2008). Data envelopment analysis: The Mathematical Programming Approach to Efficiency Analysis. In: H.O. Fried, C.A. Knox Lovell, S.S. Schmidt (eds.), The Measurement of Productive Efficiency and Productivity Growth (pp. 251-420). New York, NY: Oxford University Press.

Ubl, E. (2010). Ownership and Efficiency in the German Life Insurance Market: A DEA Bootstrap Approach. A Dissertation (toward) the Degree of Doktorin der Sozial- und Wirtschaftswissenschaften (Socialism and Economics) (Dr. rer. soc. oec.), University of Vienna, Vienna, Austria.

Viswanathan, K.S., Cummins, J.D. (2003). Ownership Structure Changes in the Insurance Industry: An Analysis of Demutualization. Journal of Risk and Insurance, 70 (3), 401-437.

Wells, B.P., Cox, L.A., Gaver, K.M. (1995). Free Cash Flow in the Life Insurance Industry. The Journal of Risk and Insurance, 62 (1), 50-66.

Wise, W. (2018). The importance of efficiency for life insurer profit: A study of Canadian life insurance companies. Theoretical and Applied Economics, 25 (4), 5-30. 
Yakob, R., Yusop, Z., Radam, A., Ismail, N. (2014). Two-Stage DEA Method in Identifying the Exogenous Factors of Insurers' Risk and Investment Management Efficiency. Sains Malaysiana (Malaysian Science), 43 (9), 1439-1450.

Yakob, R., Yusop, Z., Radam, A., Ismail, N. (2015). The relative efficiency of investment management of life insurers and takaful operators. Investment Management and Financial Innovations, 12 (1), 78-89.

Yusop, Z., Radam, A., Ismail, N., Yakob, R. (2011). Risk management efficiency of conventional life insurers and Takaful operators. Insurance Markets and Companies: Analyses and Actuarial Computations, 2 (1), 58-68. 